\title{
ENGLISH AS A FOREIGN LANGUAGE (EFL) TEACHERS' PERCEPTIONS AND USE OF MOBILE DEVICES AND APPLICATIONS
}

\author{
Elias Bensalem \\ Northern Border University, Saudi Arabia
}

\begin{abstract}
This paper reports on a study of how a group of tertiary level EFL teachers perceived and used mobile devices in their teaching and personal learning. One hundred and fifty teachers ( 66 female, 84 male) from public universities in Saudi Arabia completed an online questionnaire. Results showed that the majority of participants used mobile devices and applications in their teaching and learning. Survey data showed that the vast majority of teachers had positively perceived and frequently used mobile technologies in their teaching and personal learning. In addition, there was a correlation between teachers' use of mobile technologies in their teaching and their use in learning. There was also a correlation between how teachers perceived the value of mobile technologies in learning, and how they use them in their teaching.
\end{abstract}

Keywords: EFL, mobile devices, Web 2.0 applications, technology integration

\section{Article history:}

Received: 15 October 2019;

Reviewed: 6 November 2019;

Revised: 29 November 2019;

Accepted: 7 December 2019;

Published: 30 December 2019

\section{Copyright (C) 2019 Elias Bensalem}

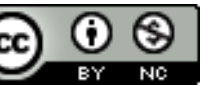

This open access article is published and distributed under a CC BY-NC 4.0 International License which permits non-commercial use, distribution, and reproduction in any medium, provided the original author and source are credited. Permissions beyond the scope of this license may be available at bensalemelias@gmail.com. If you want to use the work commercially, you must first get the authors' permission.

OpenData: Data for this study is available under a CC-BY 4.0 license at https://doi.org/10.6084/m9.figshare.11473509.v1

Citation: Bensalem, E. (2019). English as a Foreign Language (EFL) Teachers' Perceptions and Use of Mobile Devices and Applications. English Studies at NBU, 5(2), 190-202.

https://doi.org/10.33919/esnbu.19.2.1

Elias Bensalem, PhD, is an Associate Professor of English language in the Department of Languages and Translation at Northern Border University. His main research interests lie in second language acquisition, methods of foreign language teaching, and technology integration in the classroom.

E-mail: bensalemelias@gmail.com

https://orcid.org/0000-0002-6018-0897

Funding: The author wishes to acknowledge the approval and the support of this research study by the grant number 7735-EAR-2018-3-9-F from the Deanship of Scientific Research at Northern Border University, Arar, K.S.A. 
The widespread use of mobile devices and proliferation of applications are reshaping the way people learn. Mobile devices include any portable, connected technology, such as basic smartphones, netbooks, tablets, and iPads (Schuller, Winters \& West, 2013). Mobile applications include social networking sites or social media sites (e.g., Facebook, Twitter), blogs, and video sharing sites (e.g., YouTube). Today's alwayson world has undoubtedly increased learning opportunities for students. It has also encouraged many instructors to consider incorporating mobile devices and applications into their teaching, given the educational benefits that can be reaped (Lai \& Lee Smith, 2017), especially considering that the majority of students own a mobile device that they use at university (Morris, Lambe, Ciccone, \& Swinnerton, 2017).

Many studies have documented the potential benefits of integrating mobile devices and applications into teaching and learning. These devices offer students the opportunity to have autonomy over their own learning. Students can switch learning contexts from formal to informal with ease (Dias \& Victor, 2017; Lai, Khaddage, \& Knezek, 2013). Mobile devices can not only allow quick access to information and course content but also foster class discussions (Shraim \& Crompton, 2015) and facilitate collaborative learning (Garofalakis, Lagiou, \& Plessas, 2013) Schroeder \& Greenbowe, 2009; Shih, 2011). Shih (2011) reported that incorporating peer assessment through the social media platform of Facebook in learning English writing has improved student writing skills and increased learning motivation.

In another study, Zou, Xiang, and Jeaco (2012) investigated the use of Web 2.0 tools in learning a foreign language among students. They found that Web 2.0 tools such as social networking sites and Wikis provided effective platforms for students to discuss language learning materials and collaborate with other individuals. Within the same vein, Vurdien (2013) explored the use of blogs as a computer-mediated tool by a group of EFL students in Spain. Findings showed that participants spent more time on planning and editing their work before submission. Furthermore, blogs have helped students to improve their writing skills via peer feedback, and enhanced their collaborative skills- yielding better quality of written products.

However, the integration of mobile devices and applications in education brings with it a number of challenges. Some of these challenges include teachers' lack of time and 
confidence to integrate new technologies, especially when their schools do not provide them with adequate training and technical support when they face technical problems (Becta, 2004). Furthermore, teachers need to figure out how to prevent these devices from turning into a source of disruption (Dahlstrom, Walker, \& Dziuban, 2014). Another challenge would be how to use mobile devices as teaching tools, rather than aides, in order to enhance learning (Lai \& Lee Smith, 2017). In fact, it is difficult to adopt and adapt to mobile-device based teaching without providing professional development opportunities (Newhouse, Williams, \& Pearson, 2006), which aim at developing teachers' technological pedagogical content knowledge. Perhaps the most prominent barrier is related to the teachers' attitudes and approach to integrating new technologies (Balanskat, Blamire, \& Kefala, 2006). Instructors' perceptions of how mobile devices and applications can be integrated in classroom practice are likely to have an effect on how learners make use of mobile technology in their learning (Lai \& Smith, 2017).

While many studies have been carried out on the benefits of technology integration into the classroom, there is an apparent dearth of literature in the foreign language teaching field about the use of mobile devices and applications in personal learning and how teachers use them in their teaching at the tertiary level (Lai \& Lee Smith, 2017; Sanchez, Cortijo, \& Javed, 2014), particularly among foreign language teachers. One of the main goals of the current paper is to help fill this gap in research. Therefore, the current study sets out to shed light on how a group of English as a foreign language (EFL) teachers from Saudi universities perceived and used mobile devices and applications in their teaching and personal learning.

The research study aimed to answer the following two questions:

1. How often did university teachers use mobile devices and applications? Is there a significant difference between male and female teachers?

2. Is there a correlation between teachers' use of mobile devices and applications in their teaching and their use in learning?

3. How did EFL teachers perceive the use of mobile devices and applications in their teaching?

4. Is there a correlation between teachers' perceptions of value of mobile device and applications in learning, and how do they use them in their teaching? 


\section{Method}

\section{Participants and procedure}

The sample for this study was 150 EFL teachers (66 females, 84 males) who participated in the study in 2019. They came from public universities in Saudi Arabia. The majority of teachers were aged between 31 to 50 (73.33\%). About 16.66\% were aged 51 or above. Only $10 \%$ of the participants were 30 or younger. In terms of academic rank, most of the participants held the position of assistant professor or a higher rank (68\%). The remaining participants were either lecturers or teaching assistants (32\%). The majority of participants have at least 6 years of teaching experience (83.34\%) while $16.66 \%$ have 5 years or less of experience in the profession. Teachers who volunteered to participate were instructed to respond to an online survey about how often they used and perceived mobile devices and applications in their learning and teaching. Given the fact that the researcher's host institution has a small number of teaching staff in the English department, faculty members from three other universities were invited to participate in the study. Prior to the beginning of the study, the questionnaire was piloted with a small number of teachers. Adjustments were made to small number of items, based on the feedback received from the participants of the pilot study.

\section{Instruments}

Background questionnaire. It was designed to elicit respondents' information related to age, gender, academic rank, and teaching experience.

The mobile devices and applications questionnaire. An adapted version from Lai and Smith's (2017) questionnaire was used to elicit how often participants made use of a list of mobile devices and applications in their learning and teaching. The frequency of use was based on a scale of 1 to $5(1=$ never, $2=$ a few times a year, $3=$ a few times a month, $4=\mathrm{a}$ few times a week, and $5=$ daily). Consistent with methods used in Lai and Smith's (2017), items were placed into three categories: never (nonuser); occasionally (a few times a month or a year); and frequently (daily or a few times a week). The second part of the questionnaire had ten items that elicited participants' perceptions of using mobile devices and applications in their teaching and learning. Items were 
measured using 5-point Likert type scales. The scale had an acceptable level of internal consistency with Cronbach's alpha coefficient of 0.77

\section{Data analysis}

Descriptive statistics (i.e., means and standard deviations) were used to summarize participants' perceptions of value of mobile technologies and applications in learning, and how they use them in their teaching. In addition, the Pearson correlation analysis was carried out to test the correlation between teachers' perceptions of value of mobile devices and applications in learning, and how they use them in their teaching. Statistical significance for all analyses was set at an alpha level of .05.

\section{Results}

1. How often did university teachers' use mobile devices and applications? Is there a significant difference between male and female teachers?

Table 1 reports EFL teachers' use of mobile devices and applications. The vast majority of EFL teachers used mobile devices both in their teaching and learning. The most frequently used devices are tablets followed by smartphones. Blogs (70\%) is the most popular application for teaching while the majority of participants used WhatsApp as their favorite application for personal learning (89.33\%). It is interesting that $31.33 \%$ of participants reported frequent use of social media in their teaching and only $23.34 \%$ of teachers frequently used social media in their learning.

Since the data is not normally distributed, Mann-Whitney $U$ test was performed to determine whether there is a difference between male and female participants regarding the use of mobile technologies in their teaching and learning. Results showed no difference between males and females regarding the use of mobile technologies in teaching $(U=2697.500, p=n s$, mean rank for male teachers $=73.37$, female teachers $=76.38)$, and learning $(U=2740.000, p=$ ns, mean rank for male teachers $=75.02$, female teachers $=75.88$ ). Even in terms of individual devices and applications there is no significant difference. 
Table 1

EFL teachers' (male and female) use of mobile devices and applications (in percentage)

\begin{tabular}{llllllr} 
& \multicolumn{3}{c}{ Teaching } & \multicolumn{3}{c}{ Learning } \\
\cline { 2 - 7 } Device/application & Frequently & Occasionally & Nonuser & Frequently & Occasionally & Nonuser \\
\hline Smartphones & 48.67 & 26.67 & 24.66 & 28.67 & 39.33 & 32.00 \\
\hline Tablets & 70.66 & 21.34 & 8.00 & 38.66 & 40.00 & 21.34 \\
\hline Social media & 31.33 & 44.67 & 24.00 & 23.34 & 47.33 & 29.33 \\
\hline Podcast & 78.00 & 20.00 & 2.00 & 50.67 & 40.00 & 9.33 \\
\hline YouTube & 38.67 & 39.33 & 22.00 & 21.33 & 48.67 & 30.00 \\
\hline Blogs & 70.00 & 16.67 & 13.33 & 46.67 & 26.66 & 26.67 \\
\hline WhatsApp & 59.33 & 25.33 & 15.34 & 89.33 & 6.67 & 4.00 \\
\hline
\end{tabular}

2. Is there a correlation between teachers' use of mobile devices and applications in their teaching and their use in learning?

In order to examine the relationship between teachers' use of mobile devices and applications in their teaching $(\mathrm{M}=16.87, \mathrm{SD}=3.16)$ and their use in learning $(\mathrm{M}=$ 15.46, SD = 3.31), Spearman rank correlation was calculated and reported in Table 2. Results of the analysis showed that there was a moderate positive correlation between teachers' use of mobile devices and applications in their teaching and their use in learning, $\mathrm{r}=0.696, \mathrm{n}=150, \mathrm{p}<0.01$. Participants who frequently used mobile devices and applications tended to use the same devices and applications in their learning.

Table 2

Correlation between teachers' use of mobile devices and applications in their teaching and their use in learning

\begin{tabular}{llll} 
& & Teaching & Learning \\
\hline \multirow{2}{*}{ Teaching } & Pearson Correlation & 1 & $.696^{* *}$ \\
\cline { 2 - 4 } & Sig. (2-tailed) & 150 & .000 \\
\cline { 2 - 4 } & $\mathrm{N}$ & $.696^{* *}$ & 150 \\
\hline \multirow{2}{*}{ Learning } & Pearson Correlation & .000 & 1 \\
\cline { 2 - 4 } & Sig. (2-tailed) & 150 & 150 \\
\cline { 2 - 4 } & $\mathrm{N}$ &
\end{tabular}

Note*. Correlation is significant at the 0.01 level (2-tailed). 
3. How did EFL teachers perceive the use of mobile devices and applications in their teaching?

Table 3

Descriptive statistics of EFL teachers' (male and female) perception of the use of mobile devices and applications in their teaching.

Statement

Mean SD

1. I believe students' learning is enhanced in my lecture if mobile devices and applications are used.

$4.22 \quad 1.06$

2. I am willing to learn how to incorporate mobile devices and applications in my teaching to support students to engage in informal leaning to increase their $4.43 \quad .74$ formal learning.

3. Mobile devices and applications can help create learning opportunities for my students.

4. I have used devices and applications to create learning opportunities outside class for my students.

5. All students should have access to mobile devices to support their formal and informal learning.

6. I believe using mobile devices and applications will enable students to become knowledge producers.

7. I believe using mobile devices and applications in my teaching will increase my workload.

8. I believe using mobile devices and applications makes students less critical in using information.

9. My department supports the use of mobile devices and applications for teaching and learning.

10. I believe incorporating mobile devices and applications into teaching can improve the quality of teaching programs at my university.

Overall, EFL teachers held positive perceptions regarding the role of mobile devices and applications in teaching. As Table 3 shows most EFL teachers were willing to learn how to integrate mobile devices and applications in their teaching practice (Item 2) since they believed such devices can enhance students' learning (Item 1). They also believe that mobile devices create learning opportunities for students outside class (Item 4). In addition, it seemed that participants were ready to utilize mobile technologies in their classroom practice since they did not think such strategy would increase their workload (Item 7). It is interesting that respondents do not 
believe that access to mobile devices and applications would not help students to become knowledge producers.

4. Is there a correlation between teachers' perceptions of value of mobile device and applications in learning, and how do they use them in their teaching?

In order to examine the relationship between teachers' perceptions of value of mobile devices and applications in their teaching $(\mathrm{M}=37.00, \mathrm{SD}=6.25)$ and how they use them in their own learning $(\mathrm{M}=15.46, \mathrm{SD}=3.31)$, Spearman correlation was calculated. Results of the analysis showed that there was a weak positive correlation between teachers' use of mobile devices and applications in their teaching and their use in learning, $r=0.380, n=150, p<0.01$ (see Table 4). Respondents who valued the role of mobile devices and applications in learning tended to frequently use the same devices and applications in their learning.

Table 4

Correlation between teachers' perceptions of value the of mobile devices and applications in their teaching and how do they use them in their teaching

\begin{tabular}{llll}
\hline & & Teaching & Learning \\
\hline \multirow{2}{*}{$\begin{array}{l}\text { Teachers' perceptions of mobile } \\
\text { devices and applications in learning }\end{array}$} & Pearson Correlation & 1 & $.380^{* *}$ \\
\cline { 2 - 4 } & Sig. (2-tailed) & & .000 \\
\cline { 2 - 4 } & $\mathrm{N}$ & 150 & 150 \\
\hline \multirow{2}{*}{$\begin{array}{l}\text { Use of mobile devices and applications } \\
\text { in teaching }\end{array}$} & Pearson Correlation & $.380^{* *}$ & 1 \\
\cline { 2 - 4 } & Sig. (2-tailed) & .000 & \\
\cline { 2 - 4 } & $\mathrm{N}$ & 150 & 150 \\
\hline
\end{tabular}

Note*. Correlation is significant at the 0.01 level (2-tailed).

\section{Discussion}

Overall, teachers used mobile devices and applications frequently and had a positive perception of mobile technology usage, and they were willing to learn how to use mobile technologies. One possible explanation for this is that most participants were young and thus were more accepting of the idea of utilizing mobile devices to enhance student learning opportunities both inside and outside the classroom environment. In fact, the collected data 
showed that younger teachers were more positive about new technology use and were more willing to use it in their classes. A second explanation is related to the fact that most universities in Saudi, especially those seeking accreditation, are under the obligation to implement quality assurance measures in order to assure quality and the attainment of their performance objectives. Quality involves technology integration in teaching practices. Therefore, teachers are under pressure to use technology in the classroom in order to comply with quality standards. Furthermore, faculty members who are seeking academic promotion are required to prove utilization of technology in their own teaching. In a word, integrating technology into classroom practices is no longer an option. Most respondents acknowledged the support of their department for the use of mobile devices and applications for teaching and learning. This shows that the use of mobile technologies is a serious matter for Saudi universities. The same arguments could be used to explain the fact that there was no difference between males and females, regarding the frequency of mobile technologies use in learning, and teaching, even though technological use is usually construed as a male area of interest (Lai \& Lee Smith, 2017).

Survey data collected in this study also showed that there is a correlation between teachers' use of mobile devices and applications in their teaching and their use in personal learning. In other words, teachers who frequently use mobile devices and applications in their teaching tend to use them in their own learning. This outcome is in line with the results reported by Lai and Lee Smith (2017). In their study carried out at a New Zealand university, teachers who frequently used mobile technologies in their personal learning were highly likely to use them in their classroom teaching. Lai and Lee Smith (2017) argue that teachers should be encouraged to use mobile technologies in their leisure time, since a positive experience with mobile devices in personal learning may lead to mobile technology integration in their teaching.

Regarding the use of mobile devices and applications in teaching, most respondents exhibited positive perceptions of incorporating mobile technologies and 
applications into their classroom teaching. Most instructors in this study showed confidence in their ability to learn how to integrate mobile devices and applications into their teaching practice. They believed that mobile technologies enhance students' learning in class and create ample learning opportunities outside class. The same findings were corroborated by the results reported by Lai and Lee Smith (2017). One key reason for positive perceptions reported by participants is that new trends in teaching methods and strategies make use of mobile devices and applications to enhance language acquisition. The use of mobile devices enhances foreign language learners' vocabulary learning (e.g., Chen \& Chung, 2008; Lu, 2008; Stockwell, 2010; Thornton \& Houser, 2005) along with the major four language skills namely, speaking (e.g., Ducate \& Lomicka, 2009; Han \& Keskin, 2016); listening (e.g., Huang \& Sun, 2010), reading (Chen \& Hsu, 2008; Plana, Gimeno, \& Appel, 2013), and writing (e.g., Andujar, 2015). Similarly, some applications such as WhatsApp and Facebook have proved to be efficient learning platforms. Facebook can be used to improve language learners' grammar (Shih, 2013) and writing skills (Ajjan \& Hartshorne, 2008). Several studies have documented the efficiency of WhatsApp in boosting vocabulary learning (e.g., Bensalem, 2018; Fageeh, 2013; Basal, Yilmaz, Tanriverdi, \& Sari, 2016). Today, many of the workshops organized by Saudi universities that target EFL teachers focus on the effective ways to utilize mobile technologies in the classroom.

Finally, the current study revealed a relationship between teachers' perceptions of the value of mobile devices and applications in their teaching and how they use them in their own learning. This means that participants who had positive perceptions of the important role of mobile devices and applications were likely to frequently use mobile technologies in their learning. Comfort with using technology (Rakes, Fields, \& Cox, 2006) and overall support from institutions (see Lowther \& Ross, 2000) were cited in the literature as the main barriers to technology incorporation in the classroom. Lai and Lee Smith (2017) argue that some teachers who were interviewed in their study chose not to use mobile technologies because they did not have proper professional development. However, this did not seem to be the case for the participants of this study, who reported support from their respective departments. This may explain the lack of discrepancy between positive views of mobile technologies and their use in actual teaching and learning. 


\section{Conclusion, Limitations and Future Research}

The purpose of this study was to examine how tertiary level EFL teachers perceived and used mobile devices and applications in their teaching and personal learning. The participating teaching staff showed awareness of the benefits of using mobile technologies as tools that may enhance students' learning. This positive perception had an impact on how frequently participants used mobile devices and applications in their teaching and learning. It is argued that the support received from institutions, which are making technology integration a pressing matter, could be a key reason why teachers were engaged in using mobile technologies in their classroom practice. However, future large-scale empirical studies are needed to further validate the findings of this study. This study relied on a self-reported survey by teachers and this makes it difficult to generalize the results. Conducting interviews with a number of participants may have yielded more information about the reasons behind the motivations for preferring the use of particular applications over others. Furthermore, it would be interesting to explore any potential role played by socio-biographical factors such as age, gender, academic rank and teaching experience, in using mobile devices and applications in teaching and personal learning.

\section{References}

Andujar, A. (2016). Benefits of mobile instant messaging to develop ESL writing. System, 62, 63-76. https://doi.org/10.1016/j.system.2016.07.004

Balanskat, A., Blamire, R., \& Kefala, S. (2006). A review of studies of ICT impact on schools in Europe: European Schoolnet. Brussels, Belgium.

Basal, A., Yilmaz, S., Tanriverdi, A., \& Sari, L. (2016). Effectiveness of mobile applications in vocabulary teaching. Contemporary Educational Technology, 7(1), 47-59.

Becta (2004). A review of the research literature on barriers to the uptake of ICT by teachers. Becta, June.

Bensalem, E. 2018. The Impact of WhatsApp on EFL Students' Vocabulary Learning. Arab World English Journal (AWEJ), 9(1), 23-38. https://doi.org/10.24093/awej/vol9no1.2

Bensalem, E. (2019). Mobile devices and apps_raw data for NBU.xls (v1). [Dataset] figshare. https://doi.org/10.6084/m9.figshare.11473509.v1

Chen, C. M., \& Chung, C. J. (2008). Personalized mobile English vocabulary learning system based on item response theory and learning memory cycle. Computers \& Education, 51(2), 624-645. https://doi.org/10.1016/i.compedu.2007.06.011 
Chen, C. M., \& Hsu, S. H. (2008). Personalized intelligent m-learning system for supporting effective English learning. Educational Technology \& Society, 11(3), 153-180.

Dahlstrom, E., Walker, J. D., \& Dziuban, C. (2014). ECAR study of undergraduate students and information technology. Louisville, CO: ECAR.

Dias, L., \& Victor, A. (2017). Teaching and Learning with Mobile Devices in the 21st Century Digital World: Benefits and Challenges. European Journal of Multidisciplinary Studies, 2(5), 340-345. Retrieved from https://doi.org/10.26417/ejms.v5i1.p339-344

Ducate, L., \& Lomicka, L. (2009). Podcasting: an effective tool for honing language students' pronunciation? Language Learning \& Technology, 13, 66-86.

Fageeh, A. (2013). Effects of MALL applications on vocabulary acquisition and motivation. Arab World English Journal (AWEJ), 4(4), 420-447.

Garofalakis, J.D., Lagiou, A.V. \& Plessas, A.P. (2013). Use of web 2.0 tools for teaching physics in secondary education. International Journal of Information and Education Technology, 3(1), 6-9. https://doi.org/10.7763/IJIET.2013.V3.224

Han, T., \& Keskin, F. (2016). Using a mobile application (WhatsApp) to reduce EFL speaking anxiety. GIST Education and Learning Research Journal, 12, 29-50. https://doi.org/10.26817/16925777.243

Huang, C., \& P. Sun. (2010). Using mobile technologies to support mobile multimedia English listening exercises in daily life. In: The International Conference on Computer and Network Technologies in Education (CNTE 2010).

Lai, K. W., Khaddage, F., \& Knezek, G. (2013). Blending student technology experiences in formal and informal learning. Journal of Computer Assisted Learning, 29, 414425. https://doi.org/10.1111/jcal.12030

Lai, K.-W., \& Smith, L. (2018). Socio-demographic factors relating to perception and use of mobile technologies in tertiary teaching: Socio-demographic factors and mobile technologies. British Journal of Educational Technology, 49, 492-504. https://doi.org/10.1111/bjet.12544

Lowther, D. L., \& Ross, S. M. (2000). Teacher Technology Questionnaire (TTQ). Memphis, TN: Center for Research in Educational Policy, The University of Memphis.

Lu, M. (2008). Effectiveness of vocabulary learning via mobile phone. Journal of Computer Assisted Learning, 24(6), 515-525. https://doi.org/10.1111/j.13652729.2008.00289.x

Morris, N. P., Lambe, J., Ciccone, J., \& Swinnerton, B. (2016). Mobile technology: students perceived benefits of apps for learning neuroanatomy. Journal of Computer Assisted Learning, 32(5), 430-442. https://doi.org/10.1111/jcal.12144

Newhouse, C. P.,Williams, P. J., \& Pearson, J. (2006). Supporting mobile education for pre-service teachers. Australasian Journal of Educational Technology, 22, 289311. https://doi.org/10.14742/ajet.1288 
Plana, M. G.-C., Gimeno, A., \& Appel, C. (2013). Improving learners' reading skills through instant short messages: A sample study using WhatsApp. Paper presented at the Global perspectives on Computer-Assisted Language Learning, Glasgow.

Rakes, G. C., Fields, V. S., \& Cox, K. E. (2006). The influence of teachers' technology use on instructional practices. Journal of Research on Technology in Education, 38(1), 411-426. https://doi.org/10.1080/15391523.2006.10782467

Sanchez, R. A., Cortijo, V., \& Javed, U. (2014). Students' perceptions of Facebook for academic purposes. Computers \& Education, 70, 138-149. https://doi.org/10.1016/j.compedu.2013.08.012

Schroeder, J., \& Greenbowe, T. (2009). The chemistry of Facebook: Using social networking to create an online community for the organic chemistry laboratory. Journal of Online Education, 5, article 3. Retrieved from http://www.innovateonline.info/index.php?view5article\&id5625

Schuller C., Winters, N. \& West, M. (2013). The future of mobile learning - Implications for policy makers and planners. United Nations Educational, Scientific and Cultural Organization (UNESCO) report. Retrieved from https://unesdoc.unesco.org/ark:/48223/pf0000219637

Shih, R.C. (2011). Can web 2.0 technology assist college students in learning English writing? Integrating Facebook and peer assessment with blended learning, Australasian Journal of Educational Technology, 27(5), pp. 829-845. https://doi.org/10.14742/ajet.934

Shraim, K., \& Crompton, H. (2015). Perceptions of using smart mobile devices in higher education teaching: A case study from Palestine. Contemporary Educational Technology, 6, 301-318.

Stockwell, G. (2010). Using mobile phones for vocabulary activities: Examining the effect of the platform. Language Learning \& Technology, 14(2), 95-110. Retrieved from http://llt.msu.edu/vol14num2/stockwell.pdf

Thornton, P., \& Houser, C. (2001). Learning on the Move: Vocabulary Study via Email and Mobile Phone SMS. In C. Montgomerie \& J. Viteli (Eds.), Proceedings of World Conference on Educational Multimedia, Hypermedia and Telecommunications, 2001 (pp. 1896-1897). Chesapeake, VA: AACE.

Vurdien, R. (2013). Enhancing writing skills through blogging in an advanced English as a Foreign Language class in Spain. Computer Assisted Language Learning, 26(2), 126-143. https://doi.org/10.1080/09588221.2011.639784

Zou, B., Xiang, C.H., \& Jeaco, S. (2012). An Investigation of the Use of Wikis in English Language Learning. Chinese Journal of Applied Linguistics, 35(1), 99-116. https://doi.org/10.1515/cjal-2012-0008 